\title{
Editorial
}

\section{A Forum for Students}

\author{
Rachel Dunn, Northumbria Law School
}

Welcome to the first issue of Student Journal of Professional Practice and Academic Research! The aim of this journal is to provide students, undergraduate and postgraduate alike, the opportunity to publish the hard work they produce during their studies. Often students write and create excellent pieces of work during an academic year and do not have the means to share them with the wider field. This journal does just that and the first issue demonstrates the brilliant work of a range of students across different programmes.

In 2016, the Higher Education Academy (now Advance HE) awarded the inaugural Collaborative Award for Teaching Excellence (CATE) to the Student Law Office at Northumbria University. The journal is one of our funded CATE projects. In the spirit of the award, we wanted to continue our tradition of students and staff working together to enhance and showcase our students' work. We have a fabulous team of staff who work with students to review their pieces and get the publication ready. If you are interested in becoming a reviewer for the student journal, email us and we will add you to the list.

Even though CATE was awarded to Northumbria Law School, this does not mean that the journal is exclusive to law students in our school. We are willing to review pieces from other disciplines and universities, so send them in!

Unlike many traditional academic journals, we welcome a variety of different formats. You will see in this issue we have included both undergraduate and postgraduate posters, some accompanied with research reports. The journal prides itself on being a forum for visual and creative pieces, so if you have an idea of something you would like to publish, please get in contact with me! We also welcome reflective pieces from both students and those in the training stages of their career, audio pieces and dissertations.

This issue showcases some excellent work produced in Northumbria Law School. Our articles cover a range of topics, starting with Jade Watts exploring the ethics of eating meat, discussing philosophical arguments from Peter Singer and Richard Posner. A timely piece just after the conclusion of Veganuary 2019! 
Speaking of animals, PhD Candidate Alexander Maine explores lambs, hyenas and law as an oppressive force in Charlotte Brontë's Jane Eyre.

We have then engaged in something slightly different for a journal. We have two articles, submitted by Rebecca Wallace and Lauren Wharton, both discussing euthanasia in the context of John Stuart Mill's harm principle. We invite readers to compare and contrast both of these articles, analysing a topic which is revisited often in law.

A range of posters are appearing in this first issue. The undergraduate posters created by first year law students at Northumbria University, cover a wide variety of legal issues, from murder to surrogacy. All students on our Approaches the Law module work in groups to produce a research report and poster. We host a poster fair every year, where staff and students can peruse posters and ask students questions on their research. The posters in this issue were selected by staff as some of the best and we really wanted to share them with our readers. Alongside each poster is a short research report, for further information on the visual piece.

Finally, we also have two posters created by Solicitor Apprentices. Northumbria Law School's Solicitor Apprenticeship Degree is designed for those looking for a stimulating law degree combined with work-based learning. These posters were also part of an Approaches to Law Module and demonstrate the creativity of our Apprentices. One explores the legal protections of vulnerable adults and the other the 24 week limit imposed by the Abortion Act 1967.

We are thrilled to be sharing this first issue with you and hope you enjoy reading it as much as we have creating it. We have some exciting issues to share with you in the future, so watch this space. We are open to guest editorials and special issues, so if you are running a student event and would like to publish pieces developed during it with us, let us know! 